\title{
Microbial Properties and Dehydrogenase Activity in Semiarid Area, Kerman Province, Iran
}

\author{
Maryam Teimouri' ${ }^{1}$ Parisa Mohammadi ${ }^{1 *}$, Adel Jalili \\ ${ }^{1}$ Microbiology Department, Biological Sciences Faculty, Alzahra University, Tehran, I. R. Iran \\ ${ }^{2}$ Research Institute of Forests and Rangelands, Agricultural Research, \\ Education and Extension Organization (AREEO), Tehran, I. R. Iran
}

Received: 20 September 2017

Accepted: 10 February 2018

\begin{abstract}
Soil microbial and biochemical properties are important indicators in estimating soil degradation. This study aimed to determine the impact of site, season, and grazing on microbial population size, microbial biomass carbon, and dehydrogenase activity in two semiarid areas in Kerman Province, Iran. Soil samples were taken from four sites that were either cold or warm and either grazed or notgrazed over two seasons. Microbial count, microbial biomass carbon, and dehydrogenase activity were determined via plate count, fumigation-extraction, and colorometric methods, respectively. The statistical analysis showed a significant difference in fungal and bacterial plate count, microbial biomass, and dehydrogenase activity among the studied areas. Fungal and bacterial counts, microbial biomass carbon, and dehydrogenase activity were greater at cold sites compared to warm sites, possibly due to increased plant cover, soil organic carbon, and moisture. In addition, there was temporal variation in microbial properties and dehydrogenase activity with the increased activity of the spring samples. Grazing did not change the soil chemical properties but did alter its microbiological properties and dehydrogenase activity, indicating their greater sensitivity in estimating soil quality. Based on the measured microbial properties, the cold sites have an advantage in sustaining soil quality, and the warm sites are more likely to require protective management programs.
\end{abstract}

Keywords: bacteria, dehydrogenase, fungi, organic carbon, semiarid

\section{Introduction}

"Land degradation" is a composite term referring to a loss in productivity and land resources, such as soil, water, and biodiversity [1-2]. The term is often used interchangeably with "soil degradation," and the two are closely linked because soil degradation processes

*e-mail: p.mohammadi@alzahra.ac.ir constitute the most significant land-degradation processes. Degraded soil must be understood as the failure of all or some of the soil functions [3], such as the filtration of water [4] and retaining vegetation [5].

Estimating soil quality or degradation depends on a large number of physical, chemical, biological, and biochemical properties. It is very important to choose indicators that respond rapidly to changes in environmental factors. The microbiological and biochemical properties of soils are known to be very sensitive 


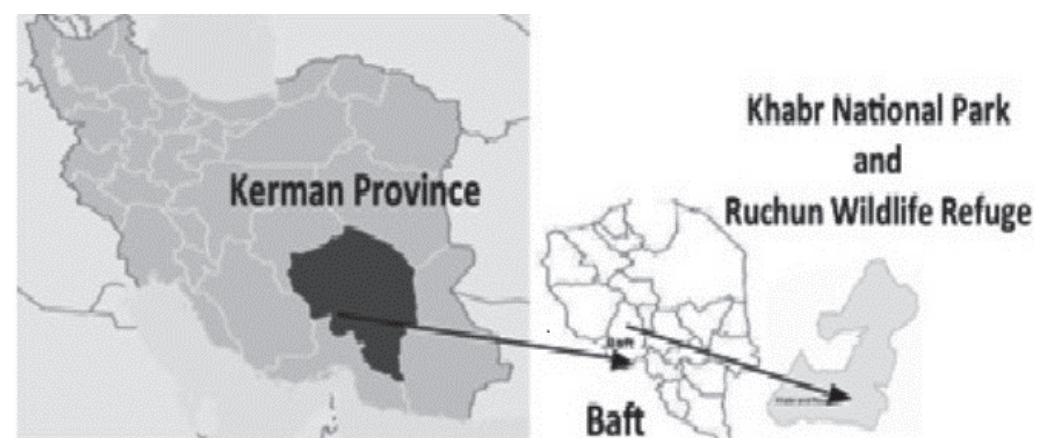

Fig. 1. Khabr National Park and Ruchun Wildlife Refuge in Baft, Kerman province, Iran.

indicators of soil quality or degradation [6-7]. There is a direct relationship between soil microbiological and biochemical properties, and that soil function and sustainability, and suitable microbial activity is required to maintain soil quality.

Iran, with an area of 1.64 million square kilometers, is located in the arid and semi-arid zone. Approximately $73 \%$ of the country has an arid and semiarid climate [8], which is vulnerable to land degradation and, in consequence, desertification due to the increasing population pressure on the land due to grazing and the consumption of water resources [9]. While the quality of a soil is related to its physical, chemical, and biological properties, only physical processes and the biology of soil flora and fauna have been relatively well studied in the semiarid areas of Iran [10-14]. Knowledge about soil microbial properties remains unclear and fragmentary in these semiarid areas [15-16]. The purpose of this study was to determine and compare the effects of site, season, and grazing on microbial population size (bacteria and fungi), microbial biomass carbon (MBC), and dehydrogenase activity, as a general index for microbial activity, over two seasons in two semiarid areas located in Khabar National Park and Ruchun Wildlife Refuge, Kerman province, Iran.

\section{Material and Methods}

\section{Study Area and Soil Sampling}

The studied area is located in the center of Iran within the semiarid steppe region of Khabr National Park and Ruchun Wildlife Refuge (Fig. 1). This national park extends from $28^{\circ} 28^{\prime}$ to $28^{\circ} 58^{\prime} \mathrm{N}$ and from $56^{\circ} 02^{\prime}$ to $56^{\circ} 38^{\prime} \mathrm{E}$. The mean annual temperature ranges between 17.5 and $21.0^{\circ} \mathrm{C}$, and precipitation ranges between 200 and $350 \mathrm{~mm}$ per year. Initially, two plots in cold sites and two plots in warm sites were selected. The altitude of the warm sites is $1,707 \mathrm{~m}$ a.s.l and is dominated by Artemisia siberi. The cold sites have an altitude of 2,365 m a.s.l. The ecosystem at the cold sites is dominated by Stipa hassknechti and A. siberi. At both the cold and warm sites, grazed and not-grazed areas were
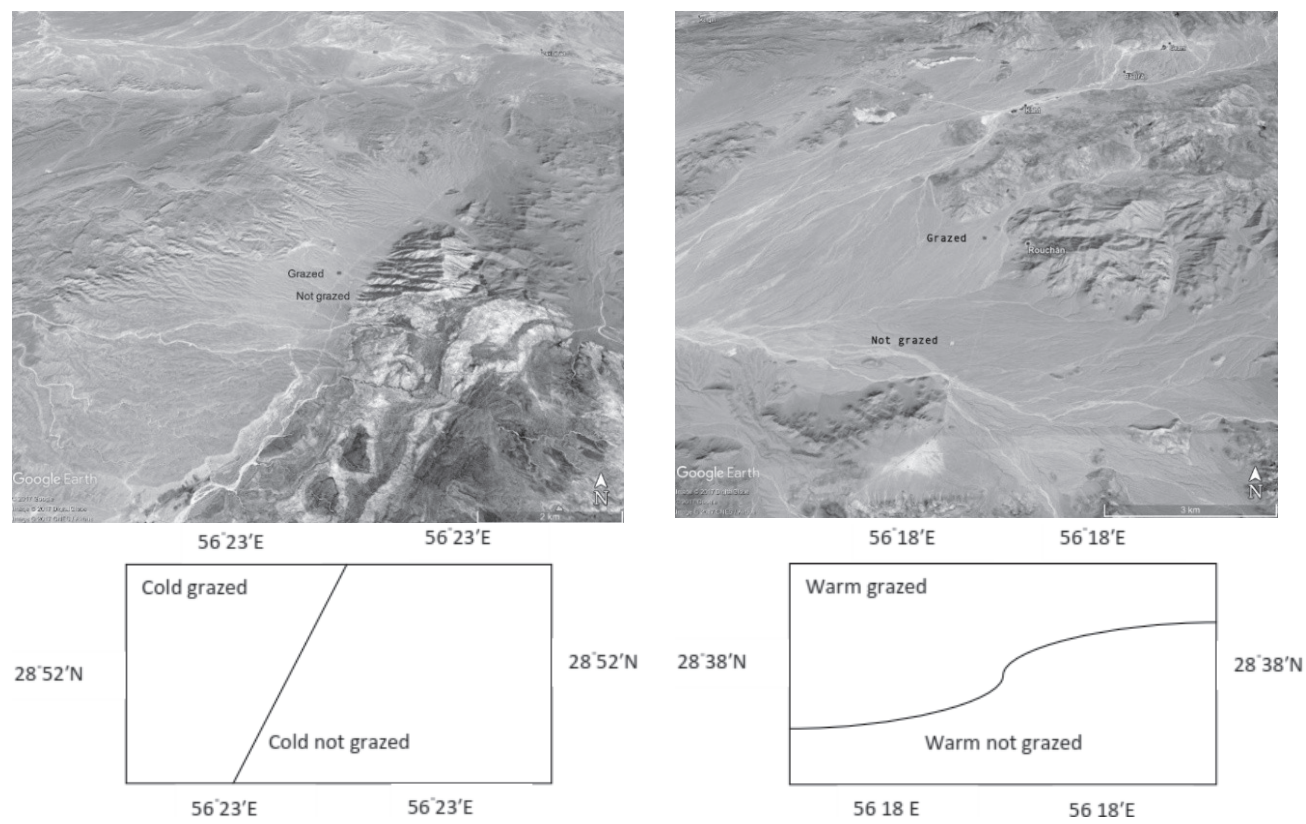

Fig. 2. Precise location of grazed and not-grazed areas in cold sites (left) and warn sites (right). 
Table 1. Mean comparison among site, season and grazing treatments.

\begin{tabular}{|c|c|c|c|c|c|c|}
\hline & \multicolumn{2}{|c|}{ Site } & \multicolumn{2}{c|}{ Season } & \multicolumn{2}{c|}{ Grazing } \\
\hline Chemical Properties & Cold & Warm & Autumn & Spring & Not-grazed & Grazed \\
\hline pH 1:2.5 water soluble & $7.75^{\mathrm{a}}$ & $7.85^{\mathrm{a}}$ & $8.3^{\mathrm{b}}$ & $7.9^{\mathrm{a}}$ & $8.75^{\mathrm{a}}$ & $7.852^{\mathrm{a}}$ \\
\hline Electrical Conductivity & $99.66^{\mathrm{a}}$ & $100.57^{\mathrm{a}}$ & $99.62^{\mathrm{a}}$ & $100.26^{\mathrm{a}}$ & $100.02^{\mathrm{b}}$ & $99.85^{\mathrm{a}}$ \\
\hline Total Nitrogen (\%) & $0.083^{\mathrm{a}}$ & $0.051^{\mathrm{b}}$ & $0.071^{\mathrm{a}}$ & $0.062^{\mathrm{b}}$ & $0.074^{\mathrm{a}}$ & $0.078^{\mathrm{a}}$ \\
\hline Available Phosphorous (mg/kg) & $35^{\mathrm{a}}$ & $35.05^{\mathrm{b}}$ & $31^{\mathrm{b}}$ & $34^{\mathrm{a}}$ & $33.1^{\mathrm{a}}$ & $34.2^{\mathrm{a}}$ \\
\hline Extractable Potassium (mg/kg) & $237.59^{\mathrm{a}}$ & $183.44^{\mathrm{b}}$ & $223.92^{\mathrm{a}}$ & $202.72^{\mathrm{b}}$ & $220.35^{\mathrm{a}}$ & $224.11^{\mathrm{a}}$ \\
\hline Soil Organic Carbon (\%) & $0.65^{\mathrm{a}}$ & $0.29^{\mathrm{b}}$ & $0.39^{\mathrm{a}}$ & $0.45^{\mathrm{a}}$ & $0.51^{\mathrm{a}}$ & $0.55^{\mathrm{a}}$ \\
\hline Soil Organic Matter $(\%)$ & $1.11^{\mathrm{a}}$ & $0.49^{\mathrm{b}}$ & $0.67^{\mathrm{a}}$ & $0.77^{\mathrm{a}}$ & $0.87^{\mathrm{a}}$ & $0.94^{\mathrm{a}}$ \\
\hline Soil Moisture $(\%)$ & $4.44^{\mathrm{a}}$ & $1.32^{\mathrm{b}}$ & $4.83^{\mathrm{a}}$ & $0.93^{\mathrm{b}}$ & $3.02 \mathrm{a}^{\mathrm{a}}$ & $3.12^{\mathrm{a}}$ \\
\hline
\end{tabular}

Soil organic matter $(\%)$ calculated by soil organic $\mathrm{C} \% \times 1.72$. Different letters show significant difference determined by LSD test $(\mathrm{p}<0.05)$.

selected (Fig. 2). Thus, in the analysis, four treatments were considered as follows: (1) cold grazed (CG), (2) cold not-grazed (CNG), (3) warm grazed (WG), and (4) warm not-grazed (WNG).

Soil sampling was performed from a plot area of $100 \times 100 \mathrm{~m}$ for the four mentioned treatments in the spring and autumn. Eight composite soil samples were collected from the top $10 \mathrm{~cm}$ of soil for each treatment, sieved ( $2 \mathrm{~mm}$ mesh) to remove plant tissues, and kept at $4^{\circ} \mathrm{C}$ until further analysis. The soil texture was sandy loam with an average of $10 \%$ clay, $30 \%$ silt, and $60 \%$ sand. The soil's chemical properties $(\mathrm{pH}$, electrical conductivity, total nitrogen, available phosphorous, extractable potassium, soil organic carbon, soil organic matter, and soil moisture) were measured according to standards methods of soil analysis.

\section{Bacteria and Fungi Count}

The plate count method was used to estimate the number of aerobic heterotrophic bacteria and filamentous fungi. Ten grams of fresh soil sample were added to $90 \mathrm{ml}$ of $0.9 \%(\mathrm{w} / \mathrm{v})$ sodium chloride solution. After homogenization for $30 \mathrm{~min}$, this solution was decimally diluted $\left(10^{-1}\right.$ to $\left.10^{-7}\right)$, and $0.1 \mathrm{ml}$ of the resulting solution was plated on suitable media and spread uniformly. Nutrient Agar (MERCK) and Saburo Dextrose Agar (MERCK) were used for culturing aerobic heterotrophic bacteria and filamentous fungi, respectively. The incubation time for bacteria and fungi was 3 and 4 days, respectively. Each dilution was plated in duplicate, and the population was expressed as the number of colonyforming units (CFUs) per $1 \mathrm{~g}$ of oven-dried soil [17].

\section{Microbial Biomass Carbon}

The microbial biomass carbon (MBC) was estimated via the chloroform fumigation-extraction method. The fumigated and non-fumigated soils (equivalent to $10 \mathrm{~g}$ of oven-dried soil) were extracted with $\mathrm{K}_{2} \mathrm{SO}_{4}$
$(0.5 \mathrm{M})$ solution and filtered. The MBC in the extract was determined via the wet oxidation-titration method [18].

\section{Dehydrogenase Activity}

Dehydrogenase activity was determined based on a method described by Schinner et al. [19]. Briefly, $5 \mathrm{~g}$ of moist soil were weighed in glass vials and treated with $2.5 \mathrm{ml}$ of $1 \%$ triphenyltetrazolium chloride (TTC)-Tris buffer. The suspensions were then incubated in the dark at $25^{\circ} \mathrm{C}$ for $16 \mathrm{~h}$. After incubation, the triphenylformazan (TPF) was extracted with acetone and estimated colorimetrically. All measurements were carried out in triplicate with one blank.

\section{Statistical Analysis}

The measured properties were subjected to analysis of variance (ANOVA), and the means were compared via the least significant difference (LSD) test $(p<0.05)$.

\section{Results and Discussion}

In this study, soil variables, including chemical properties, microbial count, microbial biomass carbon and dehydrogenase activity, were measured to determine the effects of site, season and grazing. There were significant effect on the part of site and season on soil chemical and microbial properties and dehydrogenase activity. Grazing affected soil microbial properties and dehydrogenase activity, but not soil chemical properties.

\section{Soil Chemical Properties}

Table 1 summarizes the chemical properties of the soils. There were significant effects on the part of site and season on soil chemical properties. Although the values 
of the soil chemical properties were higher in the grazed area as compared to the not-grazed area, the observed differences were not statistically significant (Table 1).

Soil $\mathrm{pH}$ and electrical conductivity (EC) are the principal indicators of the chemical characteristics of a particular soil, playing a significant role in soil biogeochemical processes, the solubility of soil nutrients, plant growth, and microbial and enzyme activity in the soil [20-21]. Soil showed alkaline reaction, which are normally found in arid/semiarid regions because little leaching and high evaporation causes ions to concentrate in the soil. Our results indicate that $\mathrm{pH}$ and electrical conductivity did not change easily due to site and grazing effects, as is supported by other studies [22-23]. The low $\mathrm{pH}$ values of the spring samples may be explained by production of $\mathrm{CO}_{2}$ via more active plant roots and bacteria, which can temporarily lower the $\mathrm{pH}$ value of natural soils [24-25].

Total nitrogen (TN), available phosphorous (AP), extractable potassium (EK), soil organic carbon (SOC), and soil organic matter (SOM) are used as important indicators of soil quality [26-27]. Regardless of season, at the cold sites, the values of TN, AP, EK, SOC, SOM, and soil moisture were higher than at the warm sites (Table 1). The higher TN, AP, EK, SOC, and SOM values at the cold sites (Table 1) may be attributed to their increased plant cover, which adds nutrients to the soil. In addition, there is some evidence that plant cover decreases nutrient loss from the soil as well [28]. The soil organic carbon threshold for sustaining soil quality is widely suggested to be about $2 \%$, below which potentially a serious decline in soil quality will occur [29]. The studied sites had low soil quality based on their SOC content (less than 2\%). The lower SOC values at warm sites as compared to cold sites likely result from the faster turnover of organic carbon and the negative correlation between temperature and soil organic carbon [30].

There was no temporal variation in SOC, but TN, AP, and EK changed seasonally (Table 1). The temporal alteration of AP occurred differently than that of total nitrogen and EK. Plants uptake more phosphorous with increasing temperature [31], thus depleting the available phosphorus in the soil from spring to autumn, which is in accordance with our results. In the spring, the observed reductions in the amounts of TN and EK may be related to the higher demands on the part of the soil biological community due to its metabolic activity.
In addition, the higher levels of TN seen in autumn can be related to the increased activity of nitrogen fixing bacteria [32]. The observed seasonal differences in soil nutrients are due to changes in soil $\mathrm{pH}$, moisture, and temperature as well [33].

\section{Soil Microbial Population Count}

Soil microbial communities are primarily composed of bacteria and fungi. Changes in soil bacteria and fungi are expected to affect soil fertility and productivity [34]. The effects of site, season and grazing were significant $(\mathrm{p}<0.05)$ on both bacterial and fungal counts. The bacterial CFUs/g soil ranged from $5.68 \times 10^{5}$ at cold sites to $2.73 \times 10^{4}$ at warm sites, from $5.25 \times 10^{5}$ in spring samples to $4.30 \times 10^{5}$ in autumn samples, and from $2.66 \times 10^{5}$ at not-grazed areas to $3.27 \times 10^{5}$ at grazed areas (Table 2). Regardless of season and grazing, increased bacterial counts were detected in the soil from the cold sites (Table 2). The fungal CFUs/g soil varied from $5.43 \times 10^{3}$ at the cold sites to $2.33 \times 10^{3}$ at the warm sites, from $3.45 \times 10^{3}$ in spring samples to $2.55 \times 10^{5}$ in autumn samples, and from $3.35 \times 10^{3}$ in not-grazed areas to $4.41 \times 10^{3}$ in grazed areas (Table 2). This value was increased for cold sites, spring samples, and not-grazed areas as compared to warm sites, autumn samples, and not-grazed areas, respectively. The increased microbial population size at cold sites may be related to their increased organic matter, plant cover, and moisture (Table 1), which all affect microbial growth [35-36]. Our findings regarding increased bacterial counts in not-grazed areas are supported by Anguita et al. [37]. However, some reports stand in contrast with our findings. Increased bacterial and fungal counts have been reported in intensively grazed areas, indicating that intensive grazing favors the proliferation of bacteria and fungi due to the increase of organic matter caused by animal excreta [38-39]. The lower fungal CFUs/g values seen in our study may be explained by the higher soil $\mathrm{pH}$ (Table 1), which is not favorable for fungal growth [39].

\section{Microbial Biomass Carbon}

Soil microbial biomass (MBC) plays a crucial role in nutrient cycling and is a sensitive indicator of the dynamics of the soil $\mathrm{C}$ and $\mathrm{N}$ cycles. Among the microbiological indicators of soil quality, microbial

Table 2. Mean comparison among sites, sampling times, and grazing on soil microbial properties.

\begin{tabular}{|c|c|c|c|c|c|c|}
\hline & \multicolumn{2}{|c|}{ Site } & \multicolumn{2}{c|}{ Season } & \multicolumn{2}{c|}{ Grazing } \\
\hline Microbial Properties & Cold & Warm & Spring & Autumn & Grazed & Not-Grazed \\
\hline Bacterial Count $(C F U / g$ soil) & $5.68 \times 10^{5 \mathrm{a}}$ & $2.55 \times 10^{4 \mathrm{~b}}$ & $5.25 \times 10^{5 \mathrm{a}}$ & $4.3 \times 10^{5 \mathrm{~b}}$ & $2.66 \times 10^{5 \mathrm{~b}}$ & $3.27 \times 10^{5 \mathrm{a}}$ \\
\hline Fungal Count $(\mathrm{CFU} / \mathrm{g}$ soil) & $5.43 \times 10^{3 \mathrm{a}}$ & $2.33 \times 10^{3 \mathrm{~b}}$ & $3.45 \times 10^{3 \mathrm{a}}$ & $2.55 \times 10^{3 \mathrm{~b}}$ & $3.35 \times 10^{3 \mathrm{~b}}$ & $4.41 \times 10^{3 \mathrm{a}}$ \\
\hline Microbial Biomass Carbon $(\mu \mathrm{g} / \mathrm{g}$ soil) & $713.98^{\mathrm{a}}$ & $516.96^{\mathrm{b}}$ & $645.12^{\mathrm{a}}$ & $522.15^{\mathrm{b}}$ & $755.519^{\mathrm{a}}$ & $475.44^{\mathrm{b}}$ \\
\hline
\end{tabular}

Different letters show significant difference determined by LSD test at $\mathrm{P}<0.05$ level. 
biomass carbon $(\mathrm{MBC})$ is one of the most promising and most commonly used due to its higher sensitivity as compared to physical and chemical properties, including soil organic carbon [40-41]. In addition, soil microbial biomass is an important indicator of soil fertility in soil ecological studies and sustainable environmental management [42-43].

The analysis of the microbial biomass carbon (MBC) data showed the significant effects on the part of site, season, and grazing on $\mathrm{MBC}$ value. MBC value was significantly higher for cold sites, spring samples and grazed areas than for warm sites, autumn samples, and not-grazed areas, respectively (Table 2). The higher MBC values at the cold sites represent an advantage in terms of maintaining soil quality. Thus, it has been proved that $\mathrm{MBC}$ values are affected by various environmental parameters. The effects of organic matter, temperature, moisture content, and $\mathrm{pH}$ on soil microbial biomass value have been reported [44-45]. The increased microbial biomass at cold sites can be explained by their increased plant cover, resulting in the increased accumulation of litter and fine roots at the cold sites as compared to warm sites. Many studies indicate the effect of plant cover density and plant diversity on MBC [46]. The increased organic matter inputs from plant litter and root exudates may have enhanced the rate of $\mathrm{MBC}$ production at the cold sites via the improved growth of microbial populations and the accumulation of $\mathrm{C}$ in the microbial biomass [47]. In addition, the positive correlations between total nitrogen and soil organic $\mathrm{C}$ and MBC have been proven in many studies [35-36, 48], which could explain the increased MBC at the cold sites as well (Table 1). Soil moisture is another important factor in microbial biomass values in soil [49-50]. The increased $\mathrm{MBC}$ observed in the soils taken from the cold sites may be related to the increased moisture at the cold sites (Table 1). Although some studies that have found no significant relationship between soil water content and microbial biomass carbon [51-52], other studies are in agreement with our findings, indicating increased MBC values as soil water content increases [53-54]. We also found increased $\mathrm{MBC}$ values in grazed areas, potentially due to the addition of organic matter via animal excreta and thus improved microbial growth. The soil microbial biomass response to grazing by livestock or other large animals is not constant and has been reported to increase or decrease in response to grazing [55]. Increased MBC values have been reported in areas with low grazing intensity [35], which supports our findings. It seems the effect of grazing depends on grazing intensity. Heavy grazing destroys the soil structure, disturbing microbial growth and the metabolism of microorganisms and thus decreasing MBC values [56-58].

\section{Dehydrogenase Activity (DHA)}

Dehydrogenases are intracellular enzymes involved in the oxidative processes of viable microbial cells. Therefore, their activity is considered a measure of overall

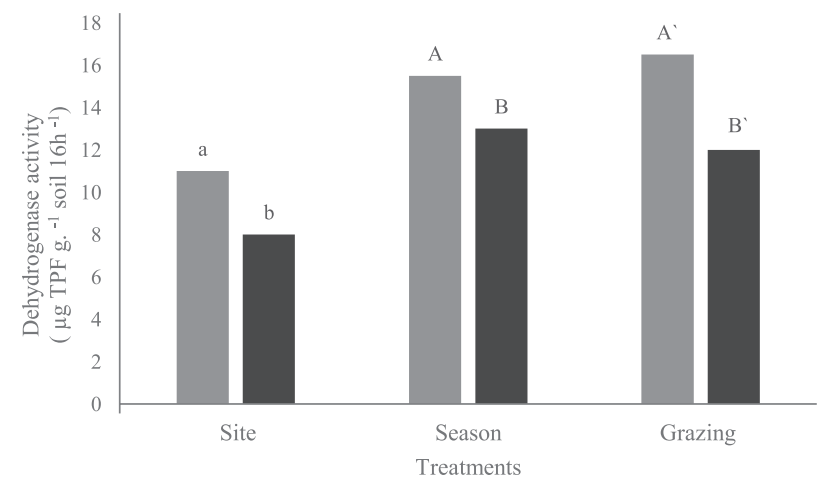

Fig. 3. Dehydrogenase activity in soil of different sites during different seasons and under grazing treatment; different letters in each treatment show significant differences determined by LSD test at $\mathrm{p}<.05$ level; a, A, $\mathrm{A}^{\prime}$ indicate more dehydrogenase activity at the cold site, spring samples, and the grazed area as compared to warm sites (b), autumn samples (B), and the not-grazed area $\left(B^{\prime}\right)$, respectively.

soil microbial activity and microbiological quality of soils [59-60]. Generally, these enzyme activities in the soil are closely related to organic matter content in the soil [61-62]. Our results indicated more dehydrogenase activity for the cold sites, spring samples, and grazed areas as compared to the warm sites, autumn samples, and not-grazed areas (Table 2 and Fig. 3). Generally, the enzyme activities in the soil were closely related to organic matter content, indicating greater biological activity in the soil and the stabilization of extracellular enzymes through complexation with humic substances [63]. The increased dehydrogenase activity at the cold sites may be explained by the increased organic matter and moisture (Table 1) at the cold sites, which is in agreement with other studies [64-66].

Variation in dehydrogenase activity was observed, with increased dehydrogenase activity being seen in the spring samples. Seasonal changes in enzyme activities are not entirely understood and depend on numerous factors, such as aeration, soil moisture, soil temperature, flora, and microflora [67]. Seasonal variation in dehydrogenase activity has been reported by others [68-69], which is in agreement with our findings. Higher levels of dehydrogenase activity in the spring is due to the better environmental conditions for microbial activity, especially temperature and moisture, in the spring, favoring the active proliferation of microbes as compared to autumn [70].

There was more dehydrogenase activity in the grazed areas as compared to the not-grazed areas (Table 2) due to the increased microbial biomass in the grazed area [50]. There are inconsistent results regarding the effect of grazing on dehydrogenase activity. Reductions of dehydrogenase activity have been reported with increased stocking rates in arid grazed areas [71-72], while others have reported increases or no change in dehydrogenase activity in the grazed area [73]. It seems that grazing intensity determines grazing effect on dehydrogenase activity. 


\section{Conclusion}

We have concluded that microbial biomass, the abundance of bacteria and fungi, and dehydrogenase activity in the surface soil were strongly influenced by various environmental factors, including organic matter, moisture, and plant cover. Grazing affected only soil microbial properties, indicating the greater sensitivity of these properties when used in soil monitoring. Based on the chemical and microbial properties and dehydrogenase activity, the quality of the soil at the warm sites is lower, and these warm sites are at risk of losing their function and becoming degraded. The warm sites require more consideration with regard to conservation programs.

\section{Conflict of Interest}

The authors declare no conflict of interest.

\section{References}

1. MAINURI Z.G., OWINO J.O. Linking landforms and land use to land degradation in the Middle River Njoro Watershed. Int Soil Water Conserve Res. 2 (1), 1, 2014.

2. STERZEL T., LU“DEKE M., KOK M., WALTHER C., SIETZ D., DE SOYSA I., LUCAS P., JANSSEN P. Armed conflict distribution in global dry lands through the lens of a typology of socio-ecological vulnerability. Reg Environ Change. 14, 1419, 2014.

3. ZORNOZA R., ACOSTA J.A., BASTIDA F., DOMÍNGUEZ S. G., TOLEDO D.M., FAZ A. Identification of sensitive indicators to assess the interrelationship between soil quality, management practices and human health. Soil. 1, 173, 2015.

4. MOL G., KEESSTRA S.D. Soil science in a changing world. Curr Opin Environ Sust. 4, 473, 2012.

5. NOVARA A., GRISTINA L., SALADINO S.S., SANTORO, A., CERDA A. Soil erosion assessment on tillage and alternative soil managements in a Sicilian vineyard. Soil Till Res. 117, 140, 2011.

6. JIMENEZ M.P., HORRA A., PRUZZO L., PALMA M.R. Soil quality: a new index based on microbiological and biochemical parameters. Biol Fert Soils. 4, 302, 2011.

7. CARDOSO E.J.B.N., VASCONCELLOS R.L.F., BINII D., MIYAUCHI M.Y.H., DOS SANTOS C.A., ALVES P.R.L. DE PAULA A.M., NAKATANI A.S., PEREIRA J.D.M., NOGUEIRA M. A. Soil health: looking for suitable indicators. What should be considered to assess the effects of use and management on soil health? Sci Agric. 70, 274, 2013.

8. KOOCHEKI A., NASIRI M., KAMALI G.A., SHAHANDEH H. Potential impacts climate change on agroclimatic indicators in Iran. Arid Land Res Manage. 20, 245, 2006.

9. AMIRASLANI F., DRAGOVICH D. Combating desertification in Iran over the last 50 years: An overview of changing approaches. J Environ Manage. 92, 1, 2011.

10. MIRZAEI J., HEYDARI M., PREVOSTO B. Effects of vegetation patterns and environmental factors on woody regeneration in semi-arid oak-dominated forests of western Iran. J Arid Land. 9, 368, 2017.
11. HESHMATI G.A. Indigenous Plant Species from the Drylands of Iran, Distribution and Potential for Habitat Maintenance and Repair. In: Combating Desertification in Asia, Africa and the Middle East. Springer, Netherland, 2013.

12. MATAJI A., KIA DALIR H., BABAIE S., JAFARI S., ATTAR ROSHAN S. Flora diversity in burned forest areas in Dehdez, Iran. Folia Forestalia Polonica. series A, 55, 33, 2013.

13. RAJABI M., LOTFALIZADEH H., MADJDZADEH M. The Family Chalcididae (Hym. Chalcidoidea) from Kerman Province, Southeastern Iran with Some New Records. Acta Zooligica Bulgarica. 63, 263. 2011.

14. MORADI N., SHAFIEI S., SEHHATISABET M. E. The snake fauna of Khabr National Park, southeast of Iran. Iran J Animal Biosystematics. 9, 41, 2013.

15. RAIESI F., RIAHI M. The influence of grazing exclosure on soil $\mathrm{C}$ stocks and dynamics, and ecological indicators in upland arid and semi-arid rangelands. Ecological Indicators. 41, 145, 2014.

16. KABIRIA V., RAIESIA F., GHAZAVI M.A. Tillage effects on soil microbial biomass, SOM mineralization and enzyme activity in a semi-arid Calcixerepts. Agriculture, Ecosystems \& Environment. 232, 73, 2016.

17. Carter M.R., Gregorich E.G. Soil sampling and methods of analysis. CRC Press. 2007.

18. AERY N.C. Mannual of environmental analysis., Ane Books.Pvt. Ltd., New Delhi. 2010.

19. SCHINNER F., KANDELER E., OHLINGER R., MARGESIN R. Methods in soil biology. Springer Verlag, Berlin. 1996

20. PIETRI J.C.A., BROOKES P.C. Nitrogen mineralization along a $\mathrm{pH}$ gradient of a silty loam UK soil, Soil Biol Biochem. 40 (3), 797, 2008

21. SINSABAUGH R.L., LAUBER C.L., WEINTRAUB M.N., AHMED B., ALLISONS. D., CRENSHAWC., CONTOSTA A.R., CUSACK D., FREY S., GALLO M. E., GARTNER T. B., HOBBIE S. E, HOLLAND K., KEELER B.L., POWERS J.S., STURSOVA M., TAKACSVESBACH C., WALDROP M.P., WALLENSTEIN M.D., ZAK D.R., ZEGLIN L. H. Stoichiometry of soil enzyme activity at global scale. Ecol Lett. 11 (11), 1252, 2008.

22. MUREITHI S., VERDOODT A., GACHENE C. K. Impact of enclosure management on soil properties and microbial biomass in a restored semi-arid rangeland, Kenya. J Arid Land. 6 (5), 561, 2014.

23. ZAREKIA S., JAFARI M., ARZANI H. Grazing Effects on Some of the Physical and Chemical Properties of Soil. World Appl Sci J. 20, 205, 2012.

24. PHILIPPOT L., RAAIJMAKERS J.M., LEMANCEAU P., VAN DER PUTTEN W.H. Going back to the roots: the microbial ecology of the rhizosphere. Nature Rev Microbiol. 11, 789, 2013.

25. SUBBARAO N.S. Soil Microbiology. New Delhi, Oxford and IBH publishing Pvt. Ltd. 2009.

26. DA SILVA M.A.G., PAVAN M.A., MUNIZ A.S., TONIN T.A., PELIZER T. Nutrient availability in soil and its absorption, transport, and redistribution in vines. Commun Soil Sci Plant. 39 (9-10), 1507, 2008.

27. WIENHOLD B.J., KARLEN D.L., ANDREWS S.S., STOT D.E. Protocol for soil management assessment framework (SMAF) soil indicator scoring curve development. Renew Agr Food Syst. 24 (4), 260, 2009.

28. PORDER S., CHADWICK O.A. Climate and soil-age constraints on nutrient uplift and retention by plants. Ecol. 90 (3), 623, 2009. 
29. LOVELAND P., WEBB J. Is there a critical level of organic matter in the agricultural soils of temperate regions: a review. Soil Till Res. 70 (1), 1, 2003.

30. KIRSCHBAUM M.U.F. The temperature dependence of soil organic matter decomposition and the effect of global warming on soil organic C storage, Soil Biol Biochem. 27 (6), 753, 1985.

31. MCCALLISTER D.L., JAWSON L.A., JAWSON M.D. Soil temperature and fumigation effects on plant phosphorus uptake and related microbial properties. J Plant Nut. 20 (4\&5), 485, 1997.

32. ZENG H.D., HU Y.L., CHANG S.X., FAN Z.P. Land cover changes effect on soil chemical and biological properties after planting Mongolian pine (Pinus sylvestris var. mongolica) in sandy lands in Keerqin, northeastern, China. Plant Soil. 317 (1-2), 121, 2009.

33. RAO A.V., TARAFDAR J.C. Seasonal changes in available phosphorus and different enzyme activities in arid soil. Ann. Arid. Zone. 31(3), 185, 1992.

34. CLASSEN A.T., SUNDQVIST M.K., HENNING J.A., NEWMAN G.S. MOORE J.A., CREGGER M.A., MOORHEAD L.C., PATTERSON C.M. Direct and indirect effects of climate change on soil microbial and soil microbial-plant interactions: What lies ahead? Ecosphere. 6, 130, 2015.

35. LIU N., ZHANG Y., CHANG S., KAN H., LIN L. Impact of Grazing on Soil Carbon and Microbial Biomass in Typical Steppe and Desert Steppe of Inner Mongolia. Plos One. 7, e36434. 2012.

36. YATING H., MINGGANG X., YUCHUN Q., YUNSHE D., XINHUA H., XINCHAO L. Differential responses of soil microbial community to four-decade long grazing and cultivation in a Semi-arid grassland. SUST. 9,128, 2017

37. ANGUITA M., PULIDO M., SCHNABEL S., LAVADOCONTADOR F., ORTEGA R., SORIANO M. Influence of livestock density on the amount and structure of soil microbial communities in rangelands of SW Spain. Geophys Res Abs. 19, EGU19323, 2017.

38. XIAOJUN N., JIANHUI Z., ZHENGAN S. Dynamics of Soil Organic Carbon and Microbial Biomass Carbon in Relation to Water Erosion and Tillage Erosion. Plose One. 8, e64059, 2013.

39. CHEN H., MOTHAPO N.V., SHI W. Soil moisture and $\mathrm{pH}$ control relative contributions of fungi and bacteria to $\mathrm{N}_{2} \mathrm{O}$ production. Microb Ecol. 69 (1), 180, 2015.

40. KASCHUK G., ALBERTON O., HUNGRIA, M. Three decades of soil microbial biomass studies in Brazilian ecosystems: Lessons learned about soil quality and indications for improving sustainability. Soil Biol Biochem. 42 (1), 1, 2010.

41. DE MORAIS PEREIRA J., BARETTA D., BINI D., DE.VASCONCELLOS R.L., CARDOSO E.G.B.N. Relationships between microbial activity and soil physical and chemical properties in native and reforested Araucaria angustifolia forests in the state of São Paulo, Brazil. Rev Bras Ciênc Solo. 37 (3), 573, 2013.

42. YADAV R. Soil organic carbon and soil microbial biomass as affected by restoration measure after 26 years of restoration in mine areas of Doon Valley. Intern J Environ Sci. 2, 1380, 2012.

43. INSAM H. Development in microbiology since the mid. Geoderma. 100, 389, 2001.

44. LIU W.X., XU W.H., HONG J.P., WAN S.Q. Internal variability of soil microbial biomass and respiration in responses to topography, annual burning and $\mathrm{N}$ addition in a semiarid temperate steppe. Geoderma 158, 259, 2010.
45. ALLISON S.D., TRESEDER K.K. Warming and drying suppress microbial activity and carbon cycling in boreal forest soils. Global Change Biol. 14, 2898, 2008.

46. RAVINDRAN A., YANG S.S. Effects of vegetation type on microbial biomass carbon and nitrogen in subalpine mountain forest soils. J Microbiol Immuno Infect. 48, 362, 2015

47. KARA O., BOLAT I. The effect of different land uses on soil microbial biomass carbon and nitrogen in Barton province. Turk J Agric. 32, 281, 2008.

48. YANG N., ZOU D., YANG M., LIN Z. Variations in Soil Microbial Biomass Carbon and Soil Dissolved Organic Carbon in the Re-Vegetation of Hilly Slopes with Purple Soil. Plos One. https://doi.org/10.1371/journal. pone.0166536, 2016.

49. NDAW S.M., GAMA-RODRIGUES A.C., GAMARODRIGUES E.F., SALES K.R., ROSADO A.S. Relationships between bacterial diversity, microbial biomass, and litter quality in soils under different plant covers in northern Rio de Janeiro State, Brazil. Can J Microbiol. 55, 1089, 2009.

50. LIU Z., LIU G., FU B.J., ZHENG X. Relationship between plant species diversity and soil microbial functional diversity along a longitudinal gradient in temperate grasslands of Hulunbeir, Inner Mongolia, China. Ecol Res. 23, 511, 2008.

51. LU X., , FAN J., YAN Y., WANG X. Comparison of Soil Microbial Biomass and Enzyme Activities among Three Alpine Grassland Types in Northern Tibet. Pol. J. Environ. Stud. 22, 437, 2013.

52. JIN H., SUN O.J., LIU J. Changes in soil microbial biomass and community structure with addition of contrasting types of plant litter in a semiarid grassland ecosystem. J Plant Ecol. 3, 209, 2010.

53. FRAZÃO L.A., PICCOLO M.C., FEIGL B.J., CERRI C.C., CERRI C.E.P. Inorganic nitrogen, microbial biomass and microbial activity of a sandy Brazilian Cerrado soil under different land uses. Agric Ecosyst Environ. 135, 161, 2010.

54. LIU X. M., LI Q., LIANG W.J., JIANG Y. Distribution of soil enzymes activities and microbial biomass along a latitudal gradient in farmlands of Songliao plane, northeast of China. Pedosphere, 18, 431, 2008.

55. YANG J., KANG Y., SAKURAI K., OHNISHI K., Siriguleng. Change of soil microbial biomass c, $\mathrm{n}$ between longtime free grazing and exclosure pasture in semiarid grassland ecosystem in Tongliao and Chifeng of Inner Mongolia. J Bioremed Biodegrad. 7, 347, 2016.

56. WANG C., LONG R. Changes in soil organic carbon and microbial biomass carbon at different degradation successional stages of alpine meadows in the headwater region of three rivers in China. J Appl Environ Biol. 14, 225, 2008.

57. WANG Q.L., WANG C.T., DU Y.G., CAO G.M. Grazing impact on soil microbial biomass carbon and relationships with soil environment in alpine Kobresia meadow. Acta Prataculturae Sinica. 17, 39, 2008.

58. BARDGETT R.D., WARDLE D.A. Herbivore mediated linkage between aboveground and belowground communities. Ecol. 84, 2258. 2003.

59. NANNIPIERI P., GIAGNONI L., RENELLA G., PUGLISI E., CECCANTI B., MASCIANDARO G., FORNASIER F., MOSCATELLI C., MARINARI, S. Soil enzymology: classical and molecular approaches. Biol Fert Soil. 48, 743, 2012

60. SHUKLA G., VARMA A. Soil Enzymology, Soil Biology 22, Springer-Verlag. Berlin Heidelberg, 2011. 
61. KANG H., SINKYU K., LEE D. Variations of soil enzyme activities in a temperate forest soil. Ecol Res. 24, 1137, 2009.

62. ADAK T., SINGHA A., KUMAR K., SHUKLA S.K, SINGH A., KUMAR SINGH V. Soil organic carbon, dehydrogenase activity, nutrient availability and leaf nutrient content as affected by organic and inorganic source of nutrient in mango orchard soil, J Soil Sci Plant Nut. 2, 394, 2014.

63. BASAK B.B., BIWAS D.R., PAL S. Soil biochemical properties and quality as affected by organic manures and mineral fertilizers in soil under maize-wheat rotation. Agrochimica. 57 (1), 49, 2013.

64. TATE R.L., TERRY R.E. Variation in Microbial Activity in Histosols and Its Relationship to Soil Moisture. Appl Environ Microb. 40, 313, 1980.

65. MARTENS D.A., JOHANSON J.B., FRANKENBERGER, W.T. JR. Production and persistence of soil enzymes with repeated addition of organic residues. Soil Sci. 153, 53, 1992.

66. BRZEZIŃSKA M., STĘPNIEWSKA Z., STĘPNIEWSKI, W. Dehydrogenase and catalase activity of soil irrigated with municipal wastewater. Pol J Environ Stud. 10, 307, 2001.

67. WOLINSKA A., STEPNIEWSKA Z. Dehydrogenase activity in the soil environment. In: Canuto R.A. (ed.): Dehydrogenases. Intech, Rijeka. Available at http://www. ebook3000.com/. 2012.
68. SARDANS J., PEÑUELAS J., ESTIARTE M. Changes in soil enzymes related to $\mathrm{C}$ and $\mathrm{N}$ cycle and in soil $\mathrm{C}$ and $\mathrm{N}$ content under prolonged warming and drought in a Mediterranean shrubland. Appl Soil Ecol. 39 (2), 223, 2008.

69. MATINIZADEH M., KORORI S.A.A., TEIMOURI M., PRAZNIK A. Enzyme activities in undisturbed and9 disturbed forest soils under oak (Quercus brantii var. persica) as affected by soil depth and seasonal variation. Asian J Plant Sci. 7 (2), 368, 2008.

70. MIRÁS AVALOS J.M., SANDE FOUZ P. Seasonal evolution of soil dehydrogenase activity at two different depths in eucalyptus stand and a cultivated field. In: Soil enzymology in the recycling of organic wastes and environmental restoration. Environmental science and engineering (environmental engineering). Springer, Berlin, Heidelberg. 2011.

71. FTERICH A., MOSBAH M., MARS M. Impact of grazing on soil microbial communities along a chronosequence of Acacia tortilis subsp. raddiana in arid soils in Tunisia. Eur J Soil Bio. 50, 56, 2012.

72. GARCIA C., ROLDAN A., HERNANDEZ T. Ability of different plant species to promote microbiological processes in semiarid soil. Geoderma. 124 (1), 193, 2005.

73. PAUDEL B.R., UDAWATTA R. P., KREMER R.J., ANDERSON S. H. Soil quality indicator responses to row crop, grazed pasture, and agroforestry buffer management. Agrofor Systmat. 84, 311, 323, 2012. 